\title{
GENERALIZED PERIODIC EEG ACTIVITY IN TWO CASES OF NEUROSYPHILIS
}

\author{
Renato Anghinah', Érica C.S. Camargo', Nádia I. Braga², \\ Simone Waksman ${ }^{1}$, Ricardo Nitrini ${ }^{1}$
}

\begin{abstract}
Neurosyphilis is a recognized cause of epileptic seizures and cognitive impairment, but is not usually associated with the finding of generalized periodic activity in the EEG. We report two similar cases characterized by pro g ressive cognitive impairment followed by partial complex seizures, in whom the EEG showed generalized periodic activity. Both cerebrospinal fluid and the response to penicillin therapy confirmed the diagnoses of neurosyphilis in the two cases. The finding of EEG generalized periodic activity in patients with cognitive or behavioral disorders is usually associated with Creutzfeldt-Jakob disease, although there are other conditions, some of them potentially reversible, which may also present this EEG abnormality. Neurosyphilis has tended not to be included among them, and our present findings support the importance of first ruling out neurosyphilis in those patients with cognitive or behavioral disorders associated with generalized periodic epileptiform discharges.
\end{abstract}

KEY WORDS: neurosyphilis, EEG, generalized periodic activity, cognitive impairment.

\begin{abstract}
Atividade periódica generalizada no EEG em dois casos de neurossífilis
RESUMO - $\mathrm{N}$ e u rossífilis é uma causa conhecida de crises convulsivas e de comprometimento cognitivo, mas não é associada geralmente a atividade periódica generalizada no eletroencefalograma (EEG). Relatamos dois casos similares caracterizados por declínio cognitivo pro g ressivo seguido de crises parciais complexas, em que o EEG mostra a atividade periódica generalizada. O líquido cefalorraquidiano e uma boa resposta à terapia com penicilina confirmaram os diagnósticos de neurossífilis nos dois casos. Achados de atividade periódica generalizada no EEG de pacientes com distúrbios cognitivos ou de comportamento são associados geralmente com a doença de Creutzfeldt-Jakob, embora haja outras circunstâncias, algumas delas potencialmente reversíveis, que podem também apresentar esta anormalidade no EEG. A neurossífilis tende a não ser incluída entre eles, e nossos achados sustentam a importância de afastar o diagnóstico de neurossífilis naqueles pacientes com declínio cognitivo ou comportamental associados com as descargas periódicas generalizadas no EEG.
\end{abstract}

PALAVRAS-CHAVE: neurossífilis, EEG, atividade periódica generalizada, comprometimento cognitivo.

Periodic activity in the electroencephalogram (EEG) was initially related to subacute sclerosing panencephalitis ${ }^{1}$. Jones and $\mathrm{Nevin}^{2}$ were the first to describe this EEG pattern in what is now classified as Creutzfeldt-Jakob disease ${ }^{3,4}$. EEG periodic activity consists of repetitive stereotyped graphoelements, mainly sharp waves or triphasic waves with generalized distribution; according to the repetition rate it is classified as short (0.5-4s) or long ( $>4 \mathrm{~s})$ periodic activi$t^{1,4}$. Short generalized periodic activity has been considered the hallmark for the diagnosis of CreutzfeldtJakob disease, although it may be present, mainly as a transient pattern, in other conditions ${ }^{3-8}$.
We now describe two cases of neurosyphilis that presented with generalized periodic activity.

\section{CASES}

Case 1 - A 35-year-old, bank clerk, right-handed man presented with a six-month pro g ressive history of bizarre behavioral manifestations, such as collecting garbage and refusing to take bath, aggressiveness and memory impairment. An EEG performed at the onset of these symptoms was normal. Two weeks prior to admission, drowsiness had developed and one week before hospitalization, he had a seizurewith clonic movements on the left side of the body lasting four hours. On examination at the tim e of admission, he was drowsy, his pupils reacted to light but were

1Departamento de Neurologia da Faculdade de Medicina da Universidade de São Paulo (FMUSP), São Paulo SP, Brasil; ${ }^{2}$ Serviço de
Neurofisiologia Clínica da Escola Paulista de Medicina da Universidade Federal de São Paulo (EPM/UNIFESP), São Paulo, SP, Brazil.

Received 24 May 2005, received in final form 18 August 2005. Accepted 10 October 2005.

Dr. Ricardo Nitrini - Rua Bartolomeu Feio 560 - 045580-001 São Paulo - Brasil. E-mail: rnitrini@uol.com.br 


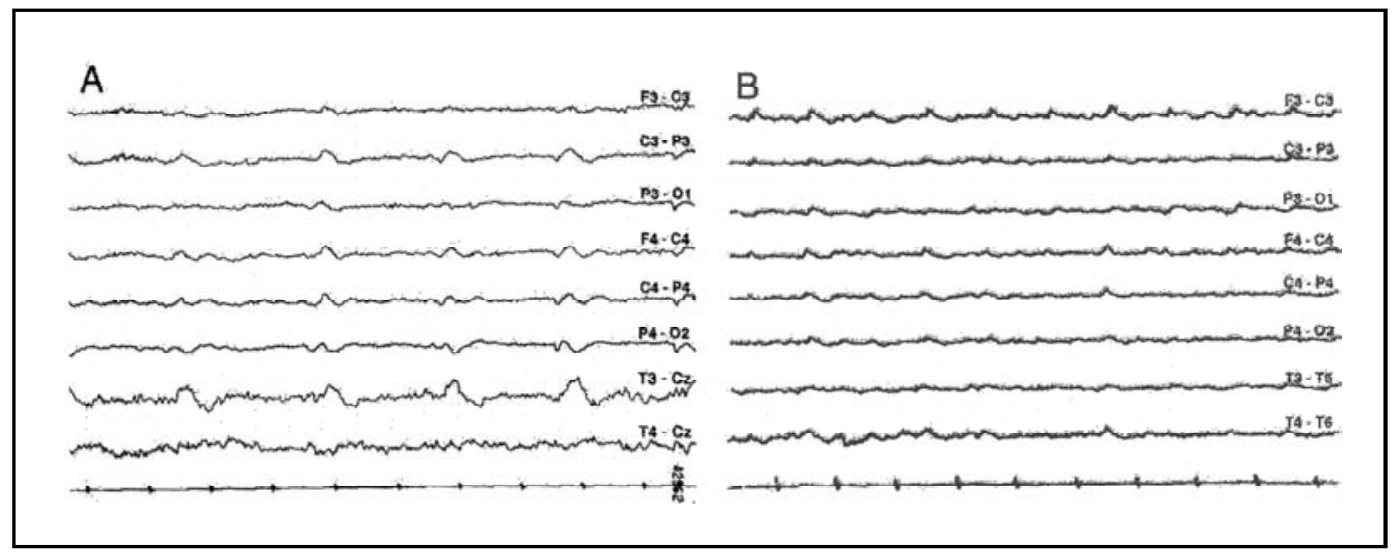

Fig 1. A) Case 1. EEG showing short generalized periodic activity (slow sharp waves). B) Case 2. EEG show ing short generalized periodic activity, most prominent over the left hemisphere, against a slow background activity. Sens.: $10 \mu \mathrm{V} / \mathrm{mm}$; TC: $0.3 \mathrm{~s}$.

asymmetric with the right pupil greater than the left, and the rewas a mild left hemiparesis. Cere b rospinal fluid (CSF) examination revealed 3 leukocytes $/ \mathrm{mm}^{3}$ (no red blood cells), $69 \mathrm{mg} / \mathrm{dL}$ glucose, $33 \mathrm{mg} / \mathrm{dL}$ protein with 35\% gammaglobulin, reagent VDRL and positive Treponema pallidum hemagglutination assay (TPHA) at a titre of 1:2048. Tests for HIV-1 were negative. Magnetic resonance imaging (MRI) showed mild ventricular enlargement and slight widening of the cortical sulci. EEG showed short generalized periodic activity (slow sharp waves), being more prominent over the right posterior areas, together with disorganization of background activity (Fig 1A). Two days after examination, EEG showed periodic lateralized epileptiform discharges (PLEDs) over the right posterior areas. The patient was treated with aqueous crystall ine penicill in G, 24 million unit is per day, administered as 4 millions units intravenously every 4 hours for 20 days starting from the second day of admission, with partial improvement. CSF examination at the end of the treatment with penicillin showed 3 leukocytes $/ \mathrm{mm}^{3}$, $65 \mathrm{mg} / \mathrm{dL}$ glucose, $21 \mathrm{mg} / \mathrm{dL}$ protein and reagent VDRL. An EEG done at time of discharge showed only disorganization of the background activity over the right hemisphere. One year later, EEG was normal, and the patient was still partially dependent and unable to work.

Case 2 - A 48-year-old, right-handed tradesman presented with one month-history of progressive memory decline and temporal and spatial disorientation. Four days prior to admission he had suffered a prolonged partial complex seizure. On examination at the time of admission, he was drowsy, his pupils were asymmetric with the left pupil greater than the right, both reacting to light, and there was a mild right hemiparesis. CSF examination revealed 42 leukocytes $/ \mathrm{mm}^{3}$, mainly lymphocytes (no red blood cells), $48 \mathrm{mg} / \mathrm{dL}$ glucose, $122 \mathrm{mg} / \mathrm{dL}$ protein with $49.6 \%$ gammaglobulin, reagent VDRL and positive TPHA at 1:512. Tests for HIV-1 were negative. MRI revealed widening of the cortical sulci most severe in the frontotemporal regions and a small area consistent with a lacunar infarct in the white matter of the right parietal lobe. EEG showed short genera- lized periodic activity, most prominent over the left hemisphere, against a slow background activity (Fig 1B). Treatment with aqueous crystalline penicillin G, 24 million unitis per day, administered as 4 millions units intravenously every 4 hours for 20 days caused partial im provement. In the second EEG, obtained 14 days after admission, no abn o rmality was found during wakefulness. CSF examination at the end of the treatment with penicillin showed 3 leukocytes $/ \mathrm{mm}^{3}, 51 \mathrm{mg} / \mathrm{dL}$ glucose, $83 \mathrm{mg} / \mathrm{dL}$ protein and reagent VDRL. One year after treatment, the patient was still unable to work.

\section{DISCUSSION}

The clinical features, CSF findings with positive immunological reactions, and the response to penicillin therapy were supportive of the diagnosis of ne u rosyphilis in both patients. EEG generalized periodic activity was seen as a transient phenomenon in both cases, and in one case it was rapidly substituted by PLEDs.

In neurosyphilis, PLEDs have been re p o rted more frequently ${ }^{9}$, while periodic generalized discharges have seldom been described. PLEDs are more frequent in EEG practice than generalized periodic epileptifomdischarges. As far as we know, the only previous report of generalized periodic activity in neurosyphilis was produced by Radhakrishnan et al., who described one case in $1984^{10}$.

Pathophysiological mechanisms responsible for the periodicity in the EEG are unknown. One hypothesis associates this condition with increased GABA hippocampal activity ${ }^{11}$, while another assumes that generalized periodic epileptiform discharges are caused by disconnection between prefrontal cortical areas and ventral tegmental area ${ }^{12}$. 
The finding of short generalized periodic epileptiformdischarges in patients with cognitive or behavioral disorders is usually associated with CreutzfeldtJakob disease, although there are other conditions, some of them potentially reversible, which may also present cognitive and behavioral disturbances associated with this EEG abnormality (see Brown ${ }^{13}$ for a review). However, neurosyphilis may manifest periodic activity as consequence either of epileptic activity or stroke caused by the encephalitic process, in both cases that we are re porting a seizure preceded the EEG abnormality.

Neurosyphilis has tended not to be included in the differential diagnosis of these conditions presenting with EEG periodic activity. However, our findings bear out the need of first ruling out neurosyphilis in those patients with cognitive or behavioral disorders associated with generalized periodic epileptiform discharges, and point to the key role of sequential EEG records tracking the evolution of encephalitic manifestations. Since tests for syphilis may be no longer be mandatory in the "routine" blood tests in patients being evaluated for dementia ${ }^{14}$, the importance of including neurosyphilis in the differential diagnosis of generalized periodic activity should be stressed.

\section{REFERENCES}

1. Gaches J. Activités periodiques en EEG. Rev EEG Neurophysiol 1971;1:9-33.
2. Jones DP, Nevin S. Rapidly prog ressive cerebral degeneration with mental disorder, focal disturbances, and myoclonic epilepsy. J Neurol Neurosurg Psychiatry 1954;17:148-159.

3. Niedermeyer E. Abnormal EEG patterns: epileptic and paroxysmal. In Niedermeyer E, Lopes da Silva F (Eds). Electroencephalography: basic principles, clinical applications, and related fields. Baltimore: Williams \& Wilkins, 1993:217-240.

4. Radermecker FJ. Aspects électroencéphalographiques dans trois cas d'encéphalite subaigue. Acta Neurol Psychiatr Belg 1949,49:222-232.

5. Takahashi M, Kubota F, Nishi Y, Miyanaga K. Persistent synchronous periodic discharges caused by anoxic encephalopathy due to cardiopulmonary arrest. Clin Electroencephalogr 1993;24:166-172.

6. KurodaY, Ikeda A, Kurohara K, et al. Occurrence of paroxysmal synchronous EEG discharges in subcortical arteriosclerotic encephalopathy. Intern Med 1993;32:243-246.

7. Isozumi K, Fukuuchi Y, Tanaka K, Nogawa S, Ishihara T, Sakuta R. A MELAS (mitochondrial myopathy, encephalopathy, latic acidosis and st rokelike episodes) mt DNA mutation that induces subacute dementia whith mimics Creutzfeldt- Jakob disease. Intern Med 1994;33:543546.

8. Yemisci M, Gurer G, Saygi S, Ciger A. Generalized periodic epileptiform discharges: clinical features, neuroradiological evaluation and prognosis in 37 adult patients. Seizure 2003;12:465-472.

9. Camacho-Salas A, Martinez-Salio A, Garcia-Morales I, Villarejo-Galende A, de la Pena P. Descargas epileptiformes lateralizadas y periódicas como forma de presentación de neurosífilis. Rev Neurol 2002;35:734737.

10. Radhakrishnan K, Ashok PP, Sridharan R, El-Mangoush MA. Periodic EEG pattern in meningovascular syphilis. J Neurol Neurosurg Psychiatry 1984;47:1360-1361.

11. Papatheodoropoulos C, Kostopoulos G.Spontaneous GABA(A)- dependent synchronous periodic activity in adult rat ventral hippocampal slices. Neurosci Lett 2002; 8:319:17-20.

12. Peters $Y$, Barnhardt NE, O'Donnell P. Pref rontal cortical up states are synchronized with tegmental area activity. Synapse 2004;52:143-152.

13. Brown P. Transmissible human spongiform encephalopathy (infectious cerebral amyloidosis): Creutzfeldt-Jakob disease, Gerstmann-SträusslerScheinker syndrome, and Kuru. Annu Rev Med 1995;46:57-65.

14. Knopman DS, DeKosky ST, Cummings JL, et al. Report of the quality standards subcommittee of the american academy of neurology. Practice parameter: diagnosis of dementia (an evidence-based review). Neurology 2001;56:1143-1153. 